\title{
Implementation of Islamic Economic Values in Online Transactions
}

\author{
Kamiruddin $^{\mathbf{1}}$, Hardianti ${ }^{2}$, Ida Farida ${ }^{3}$ \\ ${ }^{1,3}$ Department of Economics Islamic, Institut Agama Islam Negeri Bone, Indonesia \\ ${ }^{2}$ Student Economic Islamic, Institut Agama Islam Negeri Bone, Indonesia \\ kamiruddinamin@gmail.com
}

\begin{abstract}
This study examines the implementation of Islamic values in online transactions. This study aims to determine the readiness of the Raisa Collection in applying Islamic values, to determine the application of Islamic values in the Raisa Collection in online transactions, to determine the application of Islamic values in the Raisa Collection in online transactions to be used on an ongoing basis, and to determine constraints. - Constraints experienced by Raisa Collection in applying Islamic economic values in online transactions. The research method used is qualitative research using field research using data collection techniques that include observation, interviews, and documentation. The analysis technique used is descriptive analysis techniques. The results showed that: (1) Raisa Collection has tried to apply Islamic values since the beginning of its business, even though it has used bank funds. (2) In conducting its business, Raisa Collection always prioritizes customer satisfaction and continues to serve complaints from consumers. The author's implications for the Raisa Collection owner are; (1) Maintain the principles or values of Islamic economics implemented. (2) Adding sales products.
\end{abstract}

Keywords

Islamic economic values, online transactions, raisa collection

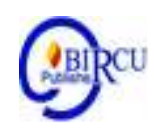

\section{Introduction}

Internet users in Indonesia currently reach 63.000 .000 people based on data from the Ministry of Communication and Information Technology (Kemenkominfo). From this data, $95 \%$ is used to access social networks. According to data from Webeshandwick, a public relations company and communication service provider, there are about 65.000 .000 active Facebook users for the Indonesian region, as many as 33.000.000 active users per day (Kementrian komunikasi dan informatika, 2020). Online crime reported around 7.047 cases from 2016 to 2020, an estimated 1.409 online fraud cases per year. From the beginning of 2020 to September 2020, online fraud was in the second position with a percentage of $28.7 \%$ of crimes. It can be seen from the number of consumers who have experienced fraud in online transactions caused by irresponsible individuals. Doing business from an Islamic perspective is not just looking for profit, but the most important thing is seeking blessings and helping others meet their needs. However, it is often encountered that business people in their activities prioritize lust and no longer listen to their conscience. Many business actors do not use Islamic economic values in their transactions, resulting in fraud, such as products that are promoted differently from the products being sold, playing with the price and quality of the goods being sold. Specific individuals sometimes use this situation because of the large number of enthusiasts from online businesses. 
Based on the various explanations above, the researcher is interested in researching the title of "Implementation of Islamic Economic Values in Online Transactions" (Raisa Collection Study Jln. Jend. Sudirman, Bone Regency). To determine if the Bone community implements Islamic economic values in online transactions or not and avoids transactions prohibited from doing business. Based on the description in the background, the researcher considers it necessary for the researcher to formulate a problem formulation which will later be used as a benchmark to make it easier for researchers to solve the main problem, including the following:

1. How is the application of Islamic economic values in online transactions at Raisa Collection?

2. Is the application of Islamic economic values in online transactions used continuously in the Raisa Collection?

\section{Review of Literature}

\subsection{Islamic Economic Values}

The Islamic economic system tries to enforce the rules of equitable distribution of wealth among members of the Muslim community by taking very effective action (Martinelli et al, 2019). The relationship between inflation and economic growth is one of the debatable issue and the most important macroeconomic discussions among macro economists, policy-makers and monetary authorities in all countries (Wollie, 2018).

In Islamic teachings, Islamic economic values in doing business have values that can be used in everyday life. Science in current Islam is based on values and must have a function and purpose because knowledge without value is like a body with no spirit (Alimuddin, 2015, p. 4). Muslim people in business expect lawful and blessed assets to deliver humans to the world's welfare and the hereafter. According to A. Hanafi and Hamid Salam in R. Lukma Fauroni, "Islamic business ethics in an Islamic perspective are Islamic ethical values in business activities" (R. Lukman Fauroni, 2006, p. 9). There are several principles or values that Muslim business people need to uphold, namely (Muhammad Djakfar, 2008, p. 100) :

a) Relying on God's provisions (tauhid),

Bertauhid is a form of acknowledgment of the Almighty God's existence (One) as a place responsible for answers to human actions that humans cannot avoid.

b) Honest in measure (quantify)

Honesty is the key to business people's success because it will build trust for trust to be fair to oneself and fair to others.

c) Sell good quality goods

One of the shortcomings in buying and selling is ignoring moral responsibilities in world business, such as the lack of transparency of a business actor regarding the quality of goods. Covering the quality of an item is the same as lying or lying to consumers. Do not lies bring discomfort; on the contrary, the truth will bring peace.

d) It is forbidden to take an oath.

It is often found in everyday life, especially among the lower class traders, known as an oath sale. They quickly take the oath to make sure that the buyer of their merchandise is really of high quality, in the hope that people are compelled to buy it. In Islam, this action is not justified because it will remove blessings. Narrated from a friend of Abu Hurairah radhiyallahu

Meaning: "The oath sells merchandise, but it takes away blessings." (HR. Bukhari no. 2087 and Muslim no. 1606) 
e) Loose and generous.

Loose and generous in the transaction, contact occurs between the seller and the buyer. In this case, a seller is expected to be friendly and courteous so that buyers will feel happy. One of the keys to success is service to others. Conversely, if the seller is not familiar, let alone rudely serve the buyer, they will run away, meaning they will not want to return.

f) Build good relationships (interrelationships) between colleagues

Islam emphasizes constructive relationships with anyone, including among business people. Islam does not want to dominate one actor over another, whether in monopoly, oligopoly, or other forms that do not reflect a sense of justice or income distribution. Rowland suggests the Japanese way of thinking that business is more of a commitment than just a transaction. Therefore personal relationships are considered very important in developing bonds of feelings and humanity.

g) Good administration.

In the world of trade, it is natural that borrowing and lending practices occur. In this connection, the Koran teaches the need to administer these accounts payable so that humans avoid mistakes that may arise, as He says. "O you who believe, if you are not in cash for a specified time, you should write it down. And let a writer among you write it down correctly ... "(Surat al-Baqarah 282) (Kementrian Agama RI, 2012, p. 48).

\subsection{Online Transactions}

The development of information technology and telecommunication has now opened up transaction processing to be carried out online. Online transactions are transactions carried out by sellers and buyers online via the internet; there is no direct encounter between buyers and sellers (Achmad, 2018). Online transactions use a sale and purchase contract called an electronic contract. This electronic contract is an agreement of the parties which is made through an electronic system. Online buying and selling transactions or orders are divided into two: buying and selling greetings and buying and selling istishna.

a. Buying and selling greetings are buying and selling with an advance payment, where the contract in buying and selling with advance payment is a greeting. According to the compilation of Islamic economic law in the book Fiqh of Sharia Economics, Mardani in Mitra Sami Gultom, et al., salam is a financing service related to buying and selling whose financing is carried out simultaneously with ordering goods. Apart from being based on the Koran and the Sunnah, the explanation of the sale and purchase of greetings in the Fatwa of the National Sharia Council (DSN) NO: 05 / DSN-MUI / IV / 2000 Regarding the sale and purchase of greetings, explains the provisions regarding payment, provisions regarding goods, provisions relating to greetings parallels, cancellation of contracts, and disputes between sellers and purchases (Mitra Sami Gultom, 2000).

b. Buying and selling istishna is a sale and purchase contract between the buyer (mustahni) and the order recipient (Sahni) for an item with certain specifications (mashnu). The specifications for the ordered goods' price must be agreed upon at the beginning of the contract. Simultaneously, the payment is made according to the agreement, whether a payment is made in advance, in installments, or deferred until a future date (Dimyauddin Djuwaini, 2010, p. 136).

Technically, istishna can be interpreted as a contract with the producer for a specific job under the account of or the sale and purchase of an item made by the producer. Buying and selling Istishna is the contact of purchasing and selling greetings because both 
are buying and selling orders, but buying and selling istishna has no stipulated payment because it can be done at the beginning or it can also be made at the end of the price (Ahmad Sarwan, 2018).

\section{Research Methods}

This research is field research. This type of research is field research with qualitative methods carried out by descriptive analysis, which describes practically the object under study and the researcher's results by first analyzing and assessing the value, according to the standard of book support in descriptive type (Suharsimin Arikunto, 1993, p. 209). The research approach used in this research is qualitative research. Qualitative research intends to understand the phenomena experienced by research subjects such as behavior, perception, motivation, action, etc. They are holistically and thorough descriptions in words and language in a particular natural context and using various natural methods (Ismail Nurdin, 2019, p. 79).

The location used as a research place is the Raisa Collection which is located at Jln. Jend. Sudirman, In front of the Bulog Office, Kelurahan Biru, Tanete Riattang District, Bone Regency, South Sulawesi. This research will initially be conducted within one month, namely February 21, 2020, to March 21, 2020. Still, because the researcher has not finished researching it within one month, the researcher has extended the study period to 2 months. In this study, collecting data is very important in research. In this study, the authors use two data sources: primary data sources (primary information) and secondary data sources (secondary data). The primary data in this study were the results of interviews with owners, employees, and parties related to the Raisa Collection. Secondary data is already available and can be obtained by researchers by reading, listening, and seeing (Sugiyono, 2015, p. 76). Research subjects are certain actors or people who are used as sources of research data. This research makes Raisa Collection business actors on Jalan Jendral Sudirman a research source. The research object is the focus of the research to be studied. The object of this research is the application of Islamic values in online transactions at the Raisa Collection. To analyze and parse the data that has been collected in the research location, the researcher needs data analysis. Researchers' data analysis technique in parsing and analyzing the data collected in this study is descriptive analysis techniques. In this technique, the researcher develops the data and summarizes several conditions and situations in the research location. Then draw a picture of the requirements, the case in the field. In qualitative data, analysis is carried out interactively and continues to completion. The data is saturated, and data analysis activities, namely data reduction, display data, and conclusion drawing/verification (Sugiyono, 2013, p. 246).

\section{Results and Discussion}

\subsection{Application of Islamic Economic Values in Online Transactions at Raisa Collection}

Islamic economic values are integrated with every movement of human life, including business activities, so it must be emphasized that in doing business not only as a place to seek profit but also as a place to strengthen brotherhood among humans and also help each other by providing products desired by consumers that way we will facilitate the work of others. Isn't it with other people's business Allah will make our business more accessible. 
Islamic economic values that Muslim business actors need to uphold are:

a. Relying on God's provisions (tauhid)

Raisa's collection in doing business is looking for profit and seeking blessings for the business being carried out by prioritizing customer satisfaction; consumers shop for 1 (one) time at the shop but can subscribe (Rahmi Nurhardi, 2020).

b. Honest in measuring/doing business (quantity)

Richard Lancaster, in Muhammad Djakfar, believes that trust is a fundamental element. Trust that results from sincerity. Sincerity is one of those character qualities that are so difficult to achieve in business, family, or other places where one's selfinterest competes with others' interests (Muhammad Djakfar, 2012, p. 35).

Raisa Collection always tries to apply honest behavior in transactions with its customers, especially product quality. In promoting goods on social media, Raisa Collection always explains its products as a description of social media posts with product material activities and prices to make it easier for consumers to see the products being promoted. There is no longer a sense of doubt (Rahmi Nurhardi, 2020).

c. Quality good selling.

The pursuit of profit with housing is linked to unfairness. It even indirectly oppressed buyers. Oppression of negative aspects of justice (Muhammad Djakfar, 2012, p. 37). "We provide goods with product standards and also some imports according to customer capabilities," said Mrs. Rahmi Raisa Collection in promoting goods on social media is transparent about the quality of the goods being advertised as well as providing products or selling products of some quality or quality, there are imported quality goods, and there is standard quality, whose prices are sold according to the quality of the goods (Rahmi Nurhardi, 2020).

d. Loose and generous

A seller is expected and generous to every friendly buyer. With this attitude, the seller will get a blessing in sales and be reduced by the buyer. It is not impossible that in the end, they will become loyal customers who will benefit from business development the day after (Muhammad Djakfar, 2012, p. 38). Raisa Collection always provides discounts or price reductions to customers who take more than 2 (two) Pcs of goods in conducting transactions with consumers. It can be seen from the posts they post on social media, Raisa's collection provides different prices for consumers who take more than 1 (one) item (Rahmi Nurhardi, 2020).

e. Build good relationships (interrelationships) between colleagues.

The Japanese business philosophy is necessary between the seller and the buyer to pursue material benefits. Still, behind it, there is the value of togetherness to maintain the cooperation built through friendship (Muhammad Djakfar, 2012, p. 39). "To get cheaper goods from manufacturers, we build good relationships with producers by becoming official agents of several brands." Said Rahmi's mother. In carrying out its business, Raisa's collection has made several collaborations with other entrepreneurs, some are permanent, and some are temporary. As Labella, Paku, and several other partner agents are not permanent (Rahmi Nurhardi, 2020).

f. Administration

Modern commercial administration practices had now been taught in the Qur'an 14 centuries ago. The point is to educate business people, be honest, avoid fraud, and avoid mistakes (Muhammad Djakfar, 2012, p. 40). "We did the recording ourselves with the learning capital of accounting during school at vocational high schools, and the recording was done every day in the sales book," said Ibu Rahmi (Rahmi Nurhardi, 2020). Raisa Collection in transactions continuously records daily, monthly, and yearly. 
The daily recording will be carried out by the shop head, while the monthly and annual recording will be carried out by the Raisa Collection owner and an inspection of the items sold.

\subsection{The Application of Islamic economic Values in Online Transactions Is Used Continuously in the Raisa Collection}

The application of Islamic economic values will create the benefit of humanity. As Allah said in QS, the problem that can be achieved in the world is making an ideal society's progress and development (Saba: 15). Being a prosperous country that Allah blesses, the earth's prosperity requires humanity to work hard and smartly based on Islamic values and not stand by or even beg. These values range from relationships with God, relationships with fellow-creatures, and behavior values (Alimuddin, 2015, p. 4).

Raisa Collection started a business to sell online with a makeshift place to sell, namely only using the house's terrace to sell and had borrowed from the bank to increase business capital until finally, Mrs. Rahmi had a large shop and a significant income too. At the beginning of her business, Rahmi always posted ready-made items as samples of products to be posted on social media and always emphasized consumer satisfaction. If there are complaints from consumers, such as defective goods, the faulty goods can be returned or exchanged for other goods at the same price (Rahmi Nurhardi, 2020).

\section{Conclusion}

The application of Islamic economic values in online transactions at the Raisa Collection has been carried out since the beginning of its business, such as relying on God's provisions (tauhid), being honest in measuring business (quantity), selling goods of good quality, loose and generous with consumers, Build good relationships (interrelationships) between colleagues and Order in administration. The application of Islamic economic values in online transactions is used continuously in the Raisa Collection. From the beginning of the business, it can be seen that it always emphasizes consumer satisfaction in transactions; if there is a defect in the consumer's goods, then the consumer if complaints properly. The defective goods will be replaced with goods or replaced with money following the agreement. The author provides suggestions to Raisa Collection business owners to maintain the principles or values that have been implemented and add to their selling items such as hijabs and hijab accessories. The Raisa Collection shop is well known to many people for the quality of goods at reasonable prices.

\section{References}

Achmad. (2018). Pengaruh Pengguna E-Commerce Terhadap Transaksi Online Menggunakan Konfirmasi Faktor Analisis. Factor Exacta, 11(1), 7.

Ahmad Sarwan. (2018). Ensiklopedia Fikih Indonesia. In Muamalah (p. 89).

Alimuddin. (2015). Pengelolaan Bisnis Berbasis Nilai-Nilai Islam1 (Universitas Hasanuddin (ed.)).

Dimyauddin Djuwaini. (2010). Pengantar Fiqh Muamalah. Pustaka Pelajar.

Ismail Nurdin, S. H. (2019). Meodologi Penelitian Sosial. Media Sahabat Cendekia.

Kementrian Agama RI. (2012). Al-Qurán dan Terjemahan. Kementerian Agama RI.

Kementrian komunikasi dan informatika. (2020). pengguna internet di indonesia 63 juta orang. 
Kominfo.Go.Id/Index.Php/Content/Detail/3415/Kominfo+\%3a+pengguna+internet+ di+indonesia+63+juta+orang/0/Berita_satker, Tanggal 19 0ktober 2020, Pukul 17:49.

Martinelli, I., et al. (2019). Community Economic Development Prospect Based on Wakaf Funds. Budapest International Research and Critics Institute-Journal (BIRCIJournal). P. 409-423.

Mitra Sami Gultom. (2000). Konsep Etika Bisnis Islam Terhadap Jual Beli Online Dalam Perspektif Fiqih Dan Fatwa. Jurnal Ekonomi Islam, 1(1), 76.

Muhammad Djakfar. (2008). Etika Bisnis Islam: Tataran Teoritis dan Praksi. UIN Malang Press.

Muhammad Djakfar. (2012). Etika Bisnis: Menangkap sprit ajaran Langit dan Pesan Moral Ajaran Bumi. Penebar Plus.

R. Lukman Fauroni. (2006). Etika Bisnis Dalam Islam. Pustaka Pesantren.

Rahmi Nurhardi. (2020). Interview with manager.

Sugiyono. (2013). Metodologi Penelitian Kombinasi (Mixed Methods). Alfabeta.

Sugiyono. (2015). Metode Penelitian Kuantitatif, Kualitatif dan R\&D. Alfabeta.

Suharsimin Arikunto. (1993). Prosedur Penelitian Ilmiyah: Suatu Pendekatan Praktik. Rineka Cipta.

Wollie, G. (2018). The Relationship between Inflation and Economic Growth in Ethiopia. Budapest International Research and Critics Institute-Journal (BIRCI-Journal, 264271. 